\title{
14 Endogenous vs. Exogenous Drivers in the Development of a Social Enterprise Sector
}

\author{
Slobodan Cvejić, Konstantina Zoehrer \\ and Vardan Urutyan
}

\section{Introduction}

The aim of this chapter is to discuss the role that endogenous and exogenous factors play in the constitution of a contemporary national sector of social enterprise (SE). More precisely, we will contrast nationally specific and historically rooted drivers with global, internationally diffusive drivers in order to assess their specific value for the development of social enterprise in a country. By endogenous factors, we mean authentic forms of SE-like organisations that have a history of functioning in a country, national laws and regulations rooted in that history as well as a nationally constituted institutional framework. By exogenous factors, we refer to policy initiatives, financial incentives, knowledge and management forms coming from the broader surroundings (the European Commission or EU member countries, the US, various international organisations and networks).

In our approach, two important observations underline the relevance of the topic:

- Most of the empirical evidence proves that social enterprises play significant roles in modern economies and, especially, in compensating for the weakening of the welfare state (Borzaga and Defourny 2001: 3-5; Graefe 2005: 11). Social enterprises employ a significant number of people, generate an important share of GDP and prove to be sustainable, even in periods of economic crisis (Monzón Campos and Chaves 2007, 2012, 2016; European Commission 2018).

- In many countries, social enterprises act within an organised "subsystem" that could be considered as a separate sector of economy. This subsystem is regulated by specific legal acts, involves numerous actors (public institutions, private businesses, academia, civil-sector organisations), has access to funding sources, etc. (European Commission 2015; Monzón Campos and Chaves 2007, 2012, 2016). 
If we consider social enterprises as part of the social economy, ${ }^{1}$ we can refer to Defourny and his co-authors, who state that

[N]eed is an insufficient explanation for the social mobilisation that lays behind its manifestations. The collective identity, the belonging to a group whose members were aware that they shared a common destiny, is a second rung of the explanation already developed by De Tocqueville.

Defourny et al. (2001: 14)

We presume that conditions for the sustainable growth of the SE sector are met only when the inevitable global diffusion of SE goals and models meets authentic needs and historically developed, culturally conditioned practices in a country.

Based on the earlier, we hope to contribute to a better understanding of the SE sector in the countries presented and to shed more light on the possible "spots" for future policy intervention in this regard.

With a view to singling out, to the largest possible extent, the respective effects of endogenous and exogenous factors, we chose to focus on three European countries that are all characterised by their late modernisation. Indeed, in these countries, exogenous factors play a particularly important role in the development of social enterprise and can be more clearly distinguished from endogenous factors than in countries that underwent an early modernisation.

The analysis will be based, as just mentioned, on data from three countries-namely Armenia, Greece and Serbia; these countries entered modernisation after the liberation from the Ottoman rule, in the mid19th century, and they have since followed different paths of economic, political and social development. Indeed, although these three countries started with similar social and economic structures (predominance of rural population, underdeveloped economies, weak institutions), their subsequent paths of development were marked, respectively, by Soviettype socialism in Armenia, "liberal" socialism in Serbia and capitalism in Greece. These facts provide favourable ground for a comparative analysis. Our aim is to find how endogenous and exogenous drivers combine to support the development of the SE sector.

\section{How Does an SE Sector Develop?}

A recent research report reveals that, in European countries, the SE sector has reached different levels of development in terms of number and activities of social enterprises; legal and institutional framework; networking/partnerships; financial instruments/incentives; and awareness of social entrepreneurship (European Commission 2015). In addition to some common characteristics of the sector, each European country shows 
certain peculiarities, which proves that the development of a national sector of social enterprise is "authentic" to a certain extent.

The development path of the SE sector can generally be split into three stages: (1) the initial stage; (2) the institutionalisation stage; and (3) the sustainability stage. At each stage, different actors and processes exist and/or are developed to a certain extent, achieving higher functionality and better integration of the various elements cited earlierwhich then leads to a higher stage of development (Shrestha 2014). ${ }^{2}$ In the initial stage of development of social enterprise, all factors (initiatives, legal/institutional framework, networking ...) are only emerging and gradually evolving. The main feature of this phase is the fact that all factors appear, though they do not necessarily emerge at the same time and they usually develop at different paces. Since the various factors develop relatively independently, an important issue is the moment at which the whole sector transits from the initial into the institutional stage. For this to happen, not all factors need to be equally developed but all of them need to have developed at least to some extent. According to Shrestha:

At a certain stage of development, these factors come into synergy, all components institutionalise, gain their foothold in the society (in normative acts-laws, in value terms-in the public, policies of public actors, among homologous and heterologous actors), legitimise and develop further with the support of social groups and structures.

Shrestha (2014: 26)

In the sustainability stage of the sector, social enterprises are accepted and integrated into the economic and political system of a contemporary society. At this stage, the purpose and operation of social enterprises cannot be affected by changes in the political and economic system (except for radical changes in economic relations) (Shrestha 2014: 31). ${ }^{3}$

The transition from the initial to the institutional stage is very much based on the capacity of the actors involved, and primarily that of social entrepreneurs. Since the effect of their action depends on their activity as well as on the obstacles they have to face and the incentives (different types of resources) they can use, it is important to assess all these aspects. That is why, in presenting the development of social enterprise in Armenia, Greece and Serbia, we describe the following factors:

- actors in the field of social entrepreneurship: primarily not only social enterprises, social and other cooperatives and social entrepreneurs but also civil-society organisations, governments and state institutions, corporate sector and financial institutions;

- networking and partnerships among different actors on various bases and at different levels; 


\section{Cvejić, Zoehrer \& Urutyan}

- legislative frameworks (laws and other legal regulations that define legal forms and operations of social enterprises);

- financial mechanisms, instruments and incentives for the development of social entrepreneurship (donations, loans, investments, tax exemptions, etc.);

- role of social enterprises in social policy and social care;

- awareness of social entrepreneurship among citizens (best examples of social enterprises known to the public, citizens informed about social entrepreneurship, etc.).

The rise of social enterprise has occurred in a globalised world, and it has largely been boosted through the diffusion of ideas, resources, organisational patterns, networks, as much as it is influenced by the national legacy of-broadly speaking - the social economy. To explain the development of social enterprise in the three countries analysed, we borrow elements from the path-dependency theory (Stark 1994; Granovetter 2002; Ebbinghaus 2005). On such a basis, we may state that the development path of the SE sector in each country is marked by historical specificities, and that the combination of endogenous and exogenous factors shapes specific steps of development for each country's social enterprises. It appears that the degree of importance of each of these groups of factors depends not only on the level of resources and organisational capacity of social enterprises but also on the prevalence of solidarity, philanthropic and collectivistic values and their manifestation in the interplay between bottom-up and top-down dynamics. The latter are "strongly intertwined with the development of the welfare state systems" (European Commission 2020: 42). This fact emphasises the role of political culture in explaining the development path of social enterprises. Generally speaking, we expect countries with a tradition of political freedoms, market economy and entrepreneurship, civic activism and "horizontally arranged" (flexible, adaptable) institutions to be more in favour of the institutionalisation of social entrepreneurship than those countries that have a long history of authoritarian rule, command economy and dominance of an etatist and paternalist political culture. But institutional legacy matters as well. The development path of social enterprises is not the same in countries that were modernised earlier in history and have a long tradition of humanitarian, civic and social-economic activism, as well as recognised patterns of social entrepreneurship, as in countries that experienced belated modernisation and where social enterprises are emerging mostly ab novo. In the latter case, exogenous factors and the diffusion of external organisational and institutional models play a much stronger role than in the former. This is why we have chosen three countries that are all characterised by belated modernisation but which differ from one another in that they have taken different paths in terms of social and economic development. 


\section{Country Profiles}

Our intention is to analyse how, in Armenia, Greece and Serbia, the interplay between the forms of social enterprise that have historically been present, responding to the needs of the community, on the one hand, and the incentives for SE development and models of social enterprise implemented through international cooperation, on the other hand, leads to the development of the SE sector.

\subsection{Armenia}

Different dimensions and elements of social entrepreneurship, as well as different types of association and foundation, have been present in Armenia for a long time. However, the number of social enterprises in Armenia today remains small, and these organisations do not have their origins in traditional forms of the social economy. Throughout Armenian history, state- and market-failure problems have generally induced the creation of farmer groups and cooperatives, consumer cooperatives and other voluntary associations. The aim of these initiatives was to solve their members' common problems and to take care of social problems in their surrounding communities. These organisations were in line with the "mutual" and "community" purposes of the SE typology developed by Gordon (2015). However, during the time of socialism, which started in Armenia at the very beginning of the communist revolution in Russia, the state, which was omnipresent, suppressed all civic and communitarian initiatives and granted itself the exclusive formal right to entrepreneurship.

After the severe earthquake that hit the country in 1988 and the collapse of the Soviet Union, the consequences of the ensuing economic crisis and the war in Nagorno-Karabakh induced the creation of charity and philanthropic organisations concerned with the rehabilitation of the earthquake zone and the development of health, education and welfare systems in the country, which was in a post-socialist transition. These charities were family foundations established by the Armenian diaspora as well as branches of international charity organisations. ${ }^{4}$ The founders of these initiatives brought solid experience in business and finance management, and strengthened values of solidarity in Armenia; moreover, these foundations were able to invite other rich Armenians from the diaspora to join them and thus scale up their activities and extend their scope of operations.

The diaspora effect might be regarded as a key element in the development of an authentic Armenian stream of social enterprise, but the SE concept itself became known in Armenia only in the mid-2000s, through international development organisations, charities and donors. The first wide-scale SE development programme was introduced by the Eurasia Partnership Foundation (EPF) in 2009. ${ }^{5}$ In 2010, the programme granted 
financial support to several NGOs to initiate commercial activities and improve their financial sustainability. EPF suggested using the SE model to increase civil-society organisations' (CSOs') financial sustainability and recommended that these organisations create a separate for-profit entity (a spin-off) in order to do so, since NGOs could not, at that time, engage in commercial activities. Experts who subsequently analysed this experience considered that the social-entrepreneurship concept had been left vague; the programme concentrated on business development, without developing mechanisms for reinvesting the revenues back into non-profit organisations, and the majority of the commercial entities that had been created with the support of the programme drifted apart from their parent CSOs and disappeared from the SE sector (British Council 2015). A British Council study shows that, according to the 2014 State Business Registry, only 205 CSOs were associated with registered commercial entities (limited-liability companies), and it is unlikely that all these 205 LLCs were social enterprises. For example, only seven out of these LLCs associated with a CSO were dealing with persons with disabilities (PWDs).

So far, the concept of social enterprise has not been used by public institutions in Armenia. There is neither a definition of social enterprise in policy papers and ministry documents, nor a specific legal framework for social enterprises and social entrepreneurship. There is also a huge misunderstanding of the concept of social enterprise in the country; indeed, some organisations think that any effort to achieve financial sustainability would turn them into a social enterprise. However, thanks to continuous promotion by international donors, the concept of social enterprise is gaining popularity, becoming better known and discussed, being more frequently included in public-policy papers and gaining an increasing development potential.

We can conclude that endogenous drivers of social entrepreneurship in Armenia are currently very weak. There is a lack/interruption of the country's social-economy historical tradition, and authentic national initiatives have been emerging only thanks to a relatively recent impact of Armenian diaspora-financed foundations. Consequently, the increasing inflow of international models and incentives has not yet produced a significant effect on the consolidation of social enterprises' operations. Not only due to the absence of a national legislative and institutional framework that might support initiatives' sustainability, but also, above all, due to a very low level of awareness, among all actors, of the importance and value of social enterprises for sustainable development, we can say that the SE sector is still in its initial stage in Armenia.

\subsection{Greece}

Although the concept of social enterprise is still rather new in Greece, its development is based on a long-lasting interaction between top-down 
(state- and public-policy-led) and bottom-up (civil-society and grassroots initiatives) traditions. On the other hand, the European Commission's policies and funding mechanisms for social enterprises (Huliaras 2014: 11-12) are important exogenous factors, channelling socialentrepreneurial activities of the civil society and triggering the development of legal frameworks for social enterprises. The European Commission explicitly encouraged further policy development for the sector, specifically through the Outline Strategy and Priorities for Action to Develop the Social Economy and Social Entrepreneurship in Greece, which was conducted by an independent steering group of experts in 2013, as well as through the European support schemes for social enterprise supported by the Social Business Initiative and the Group of Experts for Social Entrepreneurship (GECES) of the European Commission.

As regards the bottom-up tradition, several actors and factors have contributed to the development of social enterprise in Greece: the church; the philanthropic tradition; the cooperative tradition, including social cooperatives; and grassroots and social movements.

As is the case in many European countries, the role of the church and of its organisations in Greece is closely linked to the provision of welfare services. The Orthodox Church provides social services, especially to vulnerable groups of the population. This role of the church goes back to the Greek Revolution of 1821 and still continues today.

Philanthropic foundations-both grant-making and non-grant-making ones-have been playing an important role in Greek society since the 19th century. Today, their activities are oriented towards developing, improving and providing social services, either on their own or through public and private organisations, thereby contributing to poverty alleviation and social cohesion.

In 1999, the legal form of limited-liability social cooperative (Koinonikoi Synetairismoi Periorismenis Evthinis, or KoiSPE), a type of workintegration social enterprise (WISE), was established. ${ }^{6}$ KoiSPEs aimed at reforming the mental-health sector by involving patients as active citizens in society; this evolution marked an important milestone in Greek legislation. This legal form was subsequently further developed under the 2011 law on the social economy and social entrepreneurship and then under its 2016 amendment law on the social and solidarity economy.

Bottom-up traditions, represented by actors in the field who contributed to the development of social enterprise, come from the social movements and the wider civil society and form the ecosystem around Greek social enterprises. This ecosystem is made of regional and local networks, such as the Association of Limited-Liability Social Cooperatives, the Network of Social-Cooperative Enterprises in Central Macedonia, Social-Cooperative Enterprises in Eastern Macedonia and Thrace, the Network of Social-Cooperative Enterprises in Crete, the Coordination of Social- and Solidarity-Economy Organisations in Attica and the Greek 
Social Entrepreneurship Forum. ${ }^{7}$ There is also a plethora of grassroots organisations that have focused their efforts—and still do-on tackling the social and economic challenges resulting from the 2010 financial crisis. Finally, international networks have been active in contributing to awareness-raising and capacity-building activities, and these activities are not restricted to specific legal or organisational forms of social enterprise.

As for top-down traditions related to SE development, they have included, since the 1980s onwards, a wide variety of laws regarding cooperatives. The aforementioned laws from 2011 to 2016 clearly referred to the challenges brought about by the economic crisis and saw the SE sector as a way to address these challenges and generate positive impacts. These laws did not refer explicitly to the term "social enterprise", though, but only to social cooperatives, and there is neither a dedicated legal framework nor a specific policy for social enterprise as such in Greece. As for the cooperative sector, it remains rather small to this day.

The role of public authorities in the development of the SE sector should also be highlighted. The attempts at implementing legislative regulation and public policies have contributed to a higher level of awareness and recognition of the sector, based on the definitions used by policymakers. At the national level, the portfolio for social enterprises falls within the competence of the Ministry of Labour, Social Insurance and Social Solidarity. In some cases, as far as policies are concerned, and especially for the legal form of (civic) cooperative, this competence is shared with/held by the Ministry of Economy and Development. At the local level, some cities support social enterprises. Such support is not limited to organisations that are incorporated and/or operating under law 4430/2016 on the social and solidarity economy; initiatives operating under other legal forms are also entitled to it, provided they meet specific criteria. Municipalities run those support programmes mostly through their municipal development agencies. Finally, there was also an initiative at the regional level in 2018, namely a regional multidisciplinary team aiming to develop an assisted bottom-up strategic and operational planning and an accredited training programme for social enterprises.

The interplay between the top-down, state-led approach, on the one hand, and the bottom-up, actors-led one, on the other, has not always resulted in efficient or adequately developed support measures or mechanisms, able to improve the environment for social enterprises (Zoehrer 2017). Challenges for the future development of social enterprise in Greece lie in characteristics of the political and economic environment, such as bureaucracy, a dysfunctional state, institutional reforms and overregulation. As Greece is facing a high unemployment rate, social enterprises, and especially social cooperatives, are often related to the public discourse on (work) integration. There are no dedicated public grants or support schemes for social enterprises, and grants from philanthropic foundations are limited, as these can only be granted to applicant 
organisations that have been recognised as non-profit by the foundations' legal departments. Social enterprises thus generate their income mainly through their economic activities, and European funds if applicable. They can also use financial tools developed by cooperative banks.

Despite the restrictions rooted in the broader political and economic status quo, the presence of social enterprise in the public dialogue has increased, which is evident from articles in the media, events and workshops dedicated to the subject. This contributes to a further institutionalisation of the SE sector and should in turn facilitate the increase of education and financing opportunities. Another, promising trend is the development of local SE ecosystems.

However, there is more to be done for the Greek SE sector to reach the sustainability stage. First, the terms and concepts of "social economy", "social and solidarity economy", "social entrepreneurship" and "social enterprise" are often used interchangeably, and the meaning of these various notions should be clarified. Secondly, from the perspective of public authorities or policymakers, "social enterprises" are not recognised as such, as there is no specific/dedicated legal form for social enterprise or recognition by a set of criteria. They register under the legal form of social cooperative or other social-economy types of organisation and have to meet specific legally binding criteria in order to be recognised as such organisations and gain access to public procurement and supporting mechanisms. This process does not include all bottom-up initiatives and sometimes excludes traditional social-economy or cooperative entities. Therefore, the various organisational forms and actors need to find a common voice in order to advance the institutionalisation process of the SE sector and bring it to the sustainability stage.

\subsection{Serbia}

Social enterprise is a rather new phenomenon in the Serbian economy and policy, in both conceptual and practical terms. Its roots are to be found in two streams of development. One stream consists of cooperatives and WISEs for people with disabilities, which are the forms traditionally recognised by the Serbian legal system. The other stream consists of new organisational forms that can be used to run a social enterprise: non-profit organisations (associations of citizens and foundations) and business companies operating as CSOs' spin-offs, development agencies and business incubators. These forms have been established in the context of the recent, post-socialist transformation of the economic and social-protection systems-which emerged late in Serbia, in comparison to other post-socialist countries.

The roots of social enterprise that can be traced back to the first stream are rather weak. Although the Kingdom of Serbia was one of the eleven founders of the International Cooperative Alliance in London in 1895, 


\section{Cvejić, Zoehrer \& Urutyan}

two peculiarities in the development of cooperatives in Serbia reduced the impact of this historical legacy. First, cooperatives were mostly developed in villages; they were producer and/or credit cooperatives (agricultural credit cooperatives), serving as a tool to protect small farmers jeopardised by the modernisation of agriculture in the early 20th century. Due to the prevalence of agriculture in the Serbian economy until the end of World War II, the cooperative spirit only spread to other spheres of the economy to a negligible extent. ${ }^{8}$ The second factor that weakened the historical legacy of the cooperative movement in Serbia was the fact that, during the time of socialism (1945-1990) and the "blocked postsocialist transformation" (1990-2000) (Lazić and Cvejić 2007), cooperatives were under the strong political influence of the state; they decreased in number and lost their democratic character. As a result, with the rapid urbanisation that occurred after World War II, the political, institutional, historical and cultural preconditions for the development of cooperative movements in cities were quite unfavourable, while the economic and social role of cooperatives in rural areas decreased significantly.

As regards WISEs, they emerged in significant numbers during the time of socialism, based on strong egalitarian values and an inclusive social policy, but they suffered from significant economic inefficiency and low productivity. In most of the cases, WISEs performed even worse than the majority of poorly performing enterprises in the declining socialist economy. For these reasons, most of the WISEs from the socialist time could not withstand the increased competitiveness within the newly established market economy.

Both cooperatives and WISEs went through significant legal and organisational changes after 2000 and, together with non-profit organisations (NPOs), they paved the way for the emergence of social enterprises. However, exogenous factors were also crucial for the introduction of the concept and the establishment of the SE sector in Serbia. The concept of social enterprise came into wider use through a couple of research projects financed by the Swedish International Development Cooperation Agency (SIDA) and the United Nations Development Programme (UNDP) and conducted in the mid-2000s by the European Movement in Serbia (EMinS), a Belgrade-based CSO (Parun Kolin and Petrušić 2007), and by SeConS, a Belgrade-based think tank and development initiative group (Cvejić et al. 2008). After a couple of years, the concept of social enterprise became widespread and even appeared in a strategic document, the National Employment Strategy 2011-2020, and in a legal act - the 2009 Act on the Professional Rehabilitation and Employment of Persons with Disability. Also worth noting is the fact that an Act on Social Enterprises was drafted in 2014. The Ministry of Labour, Employment, War Veterans and Social Affairs expressed the intention to establish a permanent team to monitor the sector and coordinate the policies relevant for social enterprises. But despite the growing role that public 
institutions have played in recent years in the development of the SE ecosystem in Serbia, civil society remains a major promoter and booster of such development. There are also notable examples of networking in the sector. The Coalition for the Development of Social Entrepreneurship, which is a network of advocacy organisations, has been very active in promoting the concept among different stakeholders, analysing the environment and the legal framework, advocating for an enabling environment and offering direct support to social enterprises. Another network in the field, the Social Economy Network Serbia (SENS), ${ }^{9}$ is the only national network that brings together social enterprises; it provides promotion tools, networking and market access for its members, and it also raises general awareness of SE models and success stories. The SENS currently has 40 members from all over Serbia, including CSOs, WISEs, business companies and cooperatives.

Since there is no separate registry of entities with SE characteristics in Serbia, we learned about social enterprise in the country from the research projects on the topic carried out so far (one in 2007 and another in 2013). Although the SE sector in Serbia is rather small, there was a visible increase as well as a change in the structure of the sector between 2007 and 2012. The number of social enterprises grew from 264 to 411 over this period, primarily thanks to the increase in the number of social enterprises operating under the form of CSO.

The development of social enterprises in Serbia reflects social-policy transformation (Žarkovic et al. 2017). Their growth is based on two major factors. The first factor refers to the authentic social needs of citizens, coupled with high social consciousness and entrepreneurial skills of civic activists who serve those needs: social enterprises address the needs that public providers are unable to meet. The other factor is the influence of foreign donors who raise awareness of different actors and provide financial and other support to social enterprises. As stated in the recent Smart Kolektiv's ${ }^{10}$ report, "international donors have played a significant role in supporting the development of the social enterprise ecosystem so far and are expected to continue to provide support, even if to a lesser degree" (Smart Kolektiv 2017: 2).

There is no formal institutional framework designed to support social enterprises, but there are initiatives by public bodies-in particular the Ministry of Labour, Employment, War Veterans and Social Affairs; the Social Inclusion and Poverty Reduction Unit of the Government; and the Office for Cooperation with Civil Society-to bring some order into the approach to this sector. These are all signs that social enterprises in Serbia have moved from the initial stage of development to the stage of institutionalisation. This statement is based on the characteristics of social enterprises and their ecosystem in Serbia. The sector is small, but active; there are inspiring experiences of social enterprises as well as concrete support from the surroundings (through different programmes and 
projects), and there are authentic new experiences that operate under various legal forms. Civil-society organisations show awareness of the role and capacities of different actors in reaching social cohesion as well as maturity and inventiveness in profiling their activities in that direction. In the period of severe crisis (2008-2012), the number of social enterprises grew, thus sustaining the number of employees. Furthermore, examples of good cooperation between the administration, the private sector and social enterprises at the local level are more prominent than before, which shows that social enterprises, as a form of social-economy organisations, can play a significant role in inclusive local development. The progress of the SE sector, from the initial stage to the institutional one, was achieved thanks to the interplay between endogenous and exogenous drivers. Foreign models and donations were crucial to raising awareness and initiating networking and institutional change, but they also fell on fertile ground: SE-like practices already existed-one of them (WISEs) with strong historical roots and another (NPOs and/or their spin-offs) with a more recent success in merging civic activism with economic performance.

\section{Comparative Analysis}

The brief analysis of the development of social enterprise in Armenia, Greece and Serbia presented in this chapter shows that these three countries started from similar historical circumstances in the mid-19th century but have currently reached different levels of SE development. We could say that, in Armenia, social enterprises have only entered the initial stage, since not all of the elements needed to form a system are present. The number of social enterprises is small, and initiatives emerge mostly through the projects of international donors, including the Armenian diaspora. Institutional and legislative settings are non-existent, financial incentives are scarce and networking is weak. Serbia is one step further than Armenia. Indeed, in Serbia, almost all the elements of the system are present: there are several forms of social enterprise, a few laws that introduce the concept, and an Act on Social Enterprises is to be drafted. Still, the legislative framework is not complete and the topic is not present in education and training institutions. All the actors involved and the wider public are familiar with the term and the practice of social enterprise; there are networks that advocate for social enterprises and certain public institutions have this topic on their agenda. We can consequently consider that Serbia has made considerable advancement in the institutionalisation stage, that is, in constituting an SE sector. Greece has gone still one step further than Serbia towards completing the institutionalisation stage. Work-integration social cooperatives and social cooperatives in general are the most prominent forms of social enterprise in the country (it should incidentally be mentioned, though, that the legal form of social 
cooperative is also used by ventures that do not have an explicit social aim). Social cooperative has been the most established form of social enterprise in Greek society for a long time, responding to different needs of citizens and communities; they have their roots in the social economy and cooperative tradition. Social cooperatives in Greece are numerous and are connected through networks, not only at the national but also at the regional level, which provides a solid backbone for a collective identity of the sector. Although there is a bottom-up development of the sector, to which the state has responded by reforming and diversifying the respective legal frameworks, the capacity of the SE sector in Greece has not yet unleashed its full growth potential. Nevertheless, the ecosystem of actors contributes to the sector's further development and to its transition from a rather early stage of institutionalisation to its completion.

In two of the three countries, namely Greece and Serbia, we can see that social enterprises play an important role in solving some problems linked to the sustainable and inclusive development of local communities. In both countries, public institutions respond to the initiatives launched by social entrepreneurs by trying to regulate the field, and to a lesser extent by providing incentives for and cooperating with social enterprises. It seems that the SE sector in both countries is at a crossroads where its own capacity for networking within the sector, coupled with the action of other actors in the surroundings (primarily civil-society organisations), will be crucial for the development of more favourable conditions for the sector to grow and enter the sustainability stage. This capacity for networking is a little greater in Greece than in Serbia, owing not only to the need to respond to increasing social needs during the austerity period but also thanks to a stronger, uninterrupted tradition of social cooperative and a longer history of democratic pluralism. Unlike what is the case in Serbia and Armenia, the roots of social-economic activities in Greece developed further based on the fact that humanitarian activities of the church, philanthropic activities of the business sector and, most importantly, authentic forms of social cooperativism have been slowly transformed in accordance with changes in the broader economic surroundings. In Serbia, these roots are shallower; they encompass work-integration social enterprises, established some 50 years ago, and non-profit organisations that perform economic activities in order to employ or economically empower their members, which is a more recent phenomenon (they have been developing since the mid-1990s). This comparison shows that the development path of the SE sector has a strong influence on its performance.

Finally, in the comparative analysis of the three national cases, it is also worth noting that the three countries have another common feature, besides sharing very similar historical starting points in terms of modernisation. Indeed, all three have experienced a significant influx of exogenous drivers of social entrepreneurship: funds, trainings, lobbying 
and networking. Greece left the door wide open to the European Commission's funds and initiatives; the other two countries find good opportunities, beyond European funds, in attracting non-European funds and establishing bilateral projects with European countries. Although a more specific and quantitative approach would be needed for a more nuanced analysis to examine how this access to external funds has concretely contributed to the development of social enterprise in each of the three countries, from a macro perspective, it seems that exogenous drivers have not achieved the same outcome in all of them. Our assumption is that the key lies in the interplay between endogenous and exogenous factors. Where an inflow of funds, knowledge and experience is streamed into a wellconsolidated domestic ecosystem, the results are more effective, contributing thus to a sustainable SE sector; and when social entrepreneurs are skilful at recognising opportunities and directing the inflow to important social goals, the efficiency of investment increases.

\section{Conclusion}

The comparative analysis presented earlier indicates that without strong endogenous drivers, exogenous factors only produce short-term and often vague effects, which contributes to the development of the myth of social enterprises and social entrepreneurship. ${ }^{11}$ This is a major reason why a top-down approach in constituting an SE sector will fail if it does not meet genuine social entrepreneurial initiatives and a collective identity in the field-and the latter is something that takes time and a lot of effort to build and maintain. For the same reason, more detailed research on the effects of the transfer of funds, knowledge and experience from more developed SE ecosystems to less developed ones is needed. It is also evident that local networking should be supported and advocacy continued in order to empower collective identity and solidarity culture in the field of social enterprises.

\section{Acknowledgements}

Section "2.3. Serbia" is a digest from the author's contribution to European Commission (2018).

\section{Notes}

1. We consider here the social economy as a sector that is distinct from the private for-profit sector and from the public sector, yet is interlinked with them in an economic system.

2. Shrestha refers to the third stage as the "developed" stage, but we find the term "sustainability" more appropriate.

3. Shrestha mentions Italy and Anglo-Saxon states as those having sustainable social enterprises, thanks not only to a highly valued and developed concept 
of entrepreneurship but also owing to a high level of awareness among citizens, who buy products and services offered by social enterprises.

4. Several diasporan Armenians initiated various successful projects and foundations that are managed as social enterprises; examples include the TUMO Centre for Creative technologies, run by the Simonian Educational Foundation (an important US-based benefactor), and the Tatev Revival Project or the UWC College, run by the IDeA Foundation (an important Russian-based benefactor).

5. See www.epfarmenia.am/en/program-portfolio/other/social-enterprise/.

6. Several legal acts, passed in the 1990s and building upon each other, are linked to the establishment of the KoiSPE legal form: Law 1667/1986 (On Civil Cooperatives and other clauses), Law 2716/1999 (establishing the legal form of limited-liability social cooperative properly speaking), and Law on the Development and Reform of Mental-Health Services and Other Provisions (Gazette A' 96/17-5-1999).

7. While the aforementioned networks operate at the regional level and/or focus on specific organisational forms, the Social Entrepreneurship Forum operates at the national level and is a platform bringing together all types of social enterprise and their supporting organisations.

8. The first Law on Economic Cooperatives, regulating cooperatives other than agricultural ones, was only introduced in 1937.

9. See www.sens.rs/.

10. Smart Kolektiv is a Belgrade-based NGO that plays a major role in the development of social entrepreneurship in Serbia. The report was commissioned by the European Bank for Reconstruction and Development (EBRD).

11. See more on myth and the demystification of social entrepreneurship in Andersson (2011) and Dey and Steyaert (2012, 2018).

\section{References}

Andersson, F. O. (2011) "Social entrepreneurship as Fetish", The Nonprofit Quarterly, Vol. 18, No. 2.

Borzaga, C. \& Defourny, J. (2001) “Conclusions: Social enterprises in Europe, a diversity of initiatives and prospects", in Borzaga, C. \& Defourny, J. (eds) The Emergence of Social Enterprise, London and New York: Routledge, pp. 350-70.

British Council (2015) "Analysis of Social Enterprises and Their Ecosystems in Armenia", Project to Support to the EU Delegation in e-Governance and Social Innovation.

Cvejić, S., Babović, M. \& Vuković, O. (2008) Mapiranje socijalnih preduzeća u Srbiji, Beograd: UNDP.

Defourny, J., Favreau, L. \& Laville, J.-L. (2001) “Introduction to an international evaluation”, in Spear, R., Defourny, J., Favreau, L. \& Laville, J.-L. (eds) Tackling Social Exclusion in Europe. The Contribution of the Social Economy, Aldershot: Ashgate Publishing Ltd, pp. 3-28.

Dey, P. \& Steyaert, C. (2012) "Social entrepreneurship: Critique and the radical enactment of the social”, Social Enterprise Journal, Vol. 8, No. 2, pp. 90-107.

Dey, P. \& Steyaert, C. (2018) "Myth in social entrepreneurship research: An inquiry into rationalist, ideological and dialectic practices of demystification", in Dey, P. \& Steyaert, C. (eds) Social Entrepreneurship, Cheltenham: Edwar Elgar Publishing. 
Ebbinghaus, B. (2005) "Can path dependence explain institutional change? Two approaches applied to welfare state reform", MPIfG Discussion Paper, No. 05/2, Cologne: Max-Planck-Institut für Gesellschaftsforschung.

European Commission (2015) A Map of Social Enterprises and Their EcoSystems in Europe. Synthesis Report, Luxembourg: Publications Office of the European Union.

European Commission (2018) Social Enterprises and Their Ecosystems in Europe. Country Fiche: Serbia (Author: Cvejić, S.), Luxembourg: Publications Office of the European Union. Available HTTP: http://ec.europa.eu/social/main.jsp?adv SearchKey=socenterfiches $\&$ mode $=$ advancedSubmit $\&$ cat $I=22$.

European Commission (2020) Social Enterprises and Their Ecosystems in Europe. Comparative Synthesis Report (Authors: Borzaga, C., Galera, G., Franchini, B., Chiomento, S., Nogales, R. \& Carini, C.), Luxembourg: Publications Office of the European Union. Available HTTP: https://europa.eu/!Qq64ny.

Gordon, M. (2015) “A typology of social enterprise 'traditions" ", ICSEM Working Papers, No. 18, Liege: The International Comparative Social Enterprise Models (ICSEM) Project.

Graefe, P. (2005) "Roll-out neoliberalism and the social economy", paper prepared for the Annual Meeting of the Canadian Political Science Association, London: University of Western Ontario, June 2, 2005.

Granovetter, M. (2002) “A theoretical agenda for economic sociology”, in Guillen, M. F, Collins, R., England, P. \& Meyer, M. (eds) The New Economic Sociology. Developments in an Emerging Field, New York: Russell Sage Foundation.

Huliaras, A. (2014) "The dynamics of civil society in Greece: Creating civic engagement from top", The Jean Monnet Papers on Political Economy, No. 10/2014. Available HTTP: www.uop.gr/images/files/huliaras.pdf (accessed on December 13, 2018).

Lazić, M. \& Cvejić, S. (2007) "Class and values in post-socialist transformation in Serbia", International Journal of Sociology, Vol. 37, No. 3.

Monzón Campos, J. L. \& Chaves, R. (2007) The Social Economy in The European Union, Brussels: European Economic and Social Committee.

Monzón Campos, J. L. \& Chaves, R. (2012) The Social Economy in the European Union, Brussels: European Economic and Social Committee.

Monzón Campos, J. L. \& Chaves, R. (2016) Recent Evolutions of the Social Economy in the European Union, Brussels: European Economic and Social Committee.

Parun Kolin, M. \& Petrušić, N. (2007) Socijalna preduzeća i uloga alternativne ekonomije u procesima evropskih integracija, Beograd: Evropski pokret u Srbiji.

Shrestha, M. (2014) Perspektive i faze razvoja socijalnog preduzetništva u Srbiji, Diplomski rad, Beograd: Univerzitet u Beogradu, Filozofski fakultet.

Smart Kolektiv (2017) The Social Enterprise Eco-System in Serbia, Belgrade: Smart Kolektiv.

Stark, D. (1994) "Path dependence and privatization strategies in East Central Europe”, East European Politics \& Societies, Vol. 6, No. 1.

Žarković Rakić, J., Aleksić Mirić, A., Lebedinski, L. \& Vladisavljević, M. (2017) "Welfare state and social enterprise in transition: Evidence from Serbia", Voluntas, Vol. 28, No. 6, pp. 2423-48. 
Zoehrer, K. (2017) “Social Entrepreneurship in Southeastern Europe-comparative analysis of the cases of Croatia, Serbia and Greece", EMES Conferences Selected Papers, ECSP-6EMES-02. Available HTTP: https://emes.net/content/ uploads/publications/social-entrepreneurship-in-southeastern-europe-compar ative-analysis-of-the-cases-of-croatia-serbia-and-greece/Best-PhD-paper-ECSP6EMES-02.pdf. 